\title{
距踵関節脱臼骨折に対するイリザロフ創外固定器の使用経験
}

\author{
佐世保市立総合病院整形外科 \\ 高 原 智 洋・牧 野 佳 朗 \\ 宮原 健 次・鳥越雄 史 \\ 白 石 公太郎・別府 綾 子
}

\section{Treatment of Dislocation and Fracture of Talo-Calcanean Joint by Ilizarov External Fixator : A Case Report}

\author{
Tomohiro Takahara, Yoshiaki Makino, Kenji Miyahara, \\ Takafumi Torigoshi, Kotaro Shiraishi, and Ayako Beppu \\ Department of Orthopedics Surgery, Sasebo City General Hospital, Nagasaki, Japan
}

\begin{abstract}
We successfully treated dislocation and fracture of the talo-calcanean joint by Ilizarov external fixator. The patient was a 63-year-old woman. She injured her left foot when she fell into a gutter on July 24, 2003. She suffered a fracture of the right fibular when she was 56 years old. She had diabetes mellitus (DM). On admission, plain X-ray films and computed tomography revealed a comminuted fracture of the anterior part of the calcaneus. The lateral part of the posterior talo-calcanean facet joint was fractured and dislocated in contact with lateral malleolus. It took two weeks to achieve good control of DM before operation. We performed open reduction using the Ilizarov external fixator. We were able to reduce the dislocation without skin incision, and the facet joint was also reduced completely. From the 4 th week after the operation, weighing started. Ilizarov external fixator was removed on the 8 th week. It is difficult to reduce dislocation without skin incision using ordinary methods for fractures with severe displacement or swelling. Half a year after the operation, she had no pain on walking and no limitation of range of motion.
\end{abstract}

Key words : Ilizarov external fixator (イリザロフ創外固定器), dislocation and fracture of talocalcanean joint (距踵関節脱臼骨折), calcaneus fracture（踵骨骨折）

\section{(要約)}

【目的】距踵関節脱臼骨折に対してイリザロフ創外固 定器を使用し, 良好な成績を得たので報告する。【症 例】 63 歳女性. 平成 15 年 7 月 24 日, 左足が側溝に 落与込み受傷. 既往歴: 糖尿病, 56 歳時の下腿骨折 初診時単純 X 線・CT で踵骨は前方に粉砕骨折を認め, 後距踵関節面は外側が脱且骨折を起こし外果に接触し ていた.【方法】血糖コントロール後の受傷後 2 週間 でイリザロフ創外固定器による骨接合術施行した。手 術に際しては皮切は加えずに脱臼の整復が可能であり,
関節面の整復む良好であった。術後 4 週で荷重開始. 術後 8 週でイリザロフ創外固定器を抜去した。これま での手術方法では今回のような高度な転位を伴う骨折 の場合, 皮切を加えなけ机ば整復は困難であった。ま た，腫脹が残存していた症例でも皮切を加えないため 手術可能であった点む有用であった。術後 6 力月の現 在, 歩行時痛や可動域制限むなく経過良好である.

\section{は じめに}

踵骨骨折の観血的治療は足部の機能回復を目標とし, 
特に，関節内骨折に対しては関節面の整復・強固な固 定力・早期運動訓練・早期荷重が重要視される，踵骨 骨折に対する観血的治療法にはWesthues 法やプレー トを用いた整復固定法などが一般に行われてきた。し かし，ピンニングによる整復では粉砕による著明な balooning の整復が困難なことがあり，腫脹が強い場 合でのプレート法は待機期間を長時間要するなどの問 題があった。今回，我々は著明な転位を来たし，踵骨 の粉砕を伴った距踵関節脱臼骨折に対して Ilizarov 創外固定器を使用し，良好な成績を得たので報告する. 症例 : 63 歳 女性 主婦 身長 $147.0 \mathrm{~cm}$ 体重 $68.0 \mathrm{~kg}$ BMI23

主訴 : 左足部の腫脹・疼痛

既往歴：糖尿病（45 歳時より内服治療中），右下腿骨 折, 白内障 (56 歳時手術施行)

現病歴：平成 15 年 7 月 24 日, 左足部が側溝に落ち込
み受傷，翌日，足部の腫脹・疼痛が増大したため当科 外来受診. 既往に糖尿病があり, 以前から両下腿の浮 腫が存在した。

来院時所見：左足関節内外側に圧痛があり，左足部は 全体的に腫脹していた。知覚・運動神経損傷はなく, 両下腿の浮腫を認めた。同日，シーネ固定後，手術目 的入院となった。

臨床検査所見：入院時データでは HbAlc は 8.5\%と高 かったためインシュリンによる治療を開始した。胸部 $\mathrm{X}$ 線・心電図・呼吸機能に明らかな異常はなく，両 下腿の著明な浮腫を認めたため造影 CT を施行したが 深部静脈血栓は認めなかった。

画像所見：図 1 の単純 X 線では，後距踵関節外側の 骨折と踵骨前方に粉砕骨折を認めた（図 1 ）。図 2 の 単純 CT では上段，左のように後距踵関節面の外側へ の脱臼骨折が明らかであり，骨片は外果に接する所ま

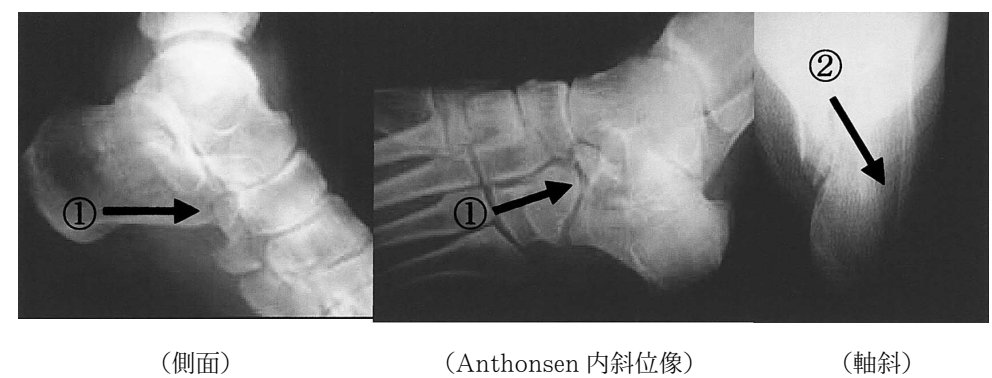

図 1 : 術前の単純 X 線では，後距踵関節外側の骨折之踵骨前方に粉砕骨折を 認めた。

(1)踵骨前方の粉砕骨折（2)踵骨外側の骨折線

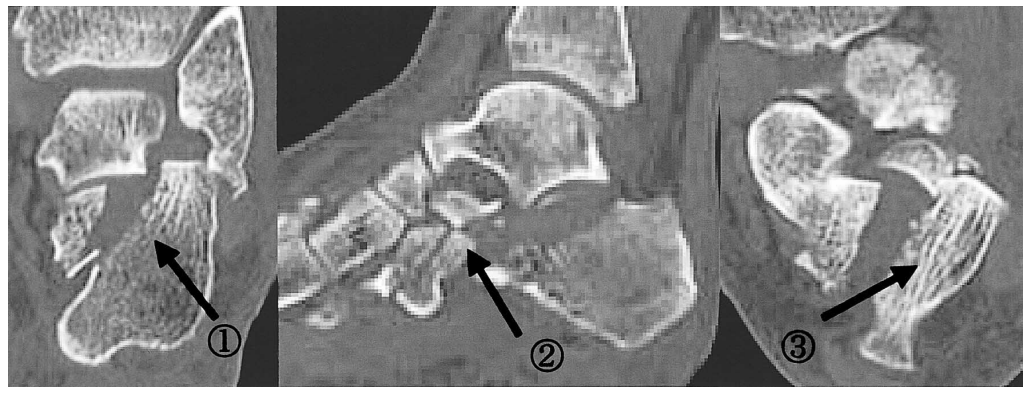

(coronal section)

(sagittal section)

(horizontal section)

図 2 : 術前の単純 CT では上段, 左のように後距踵関節面の外側への脱臼骨折 が明らかであり，骨片は外果に接する所まで逸脱していた。

(1)後距踵関節外側脱白 (2)踵骨前方の粉砕骨折 (3)踵骨骨折の外側転位 


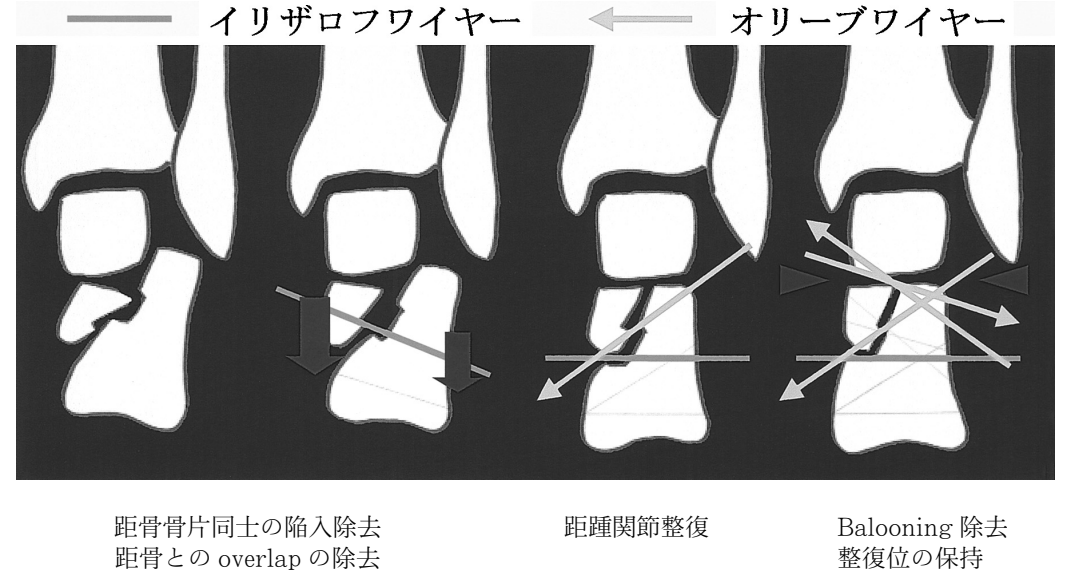

図 3：リングを装着し, 垂直方向に牽引をかけ, 内外側よりオリーブワイヤー を用いて圧迫を加え, 側方転位を整復. 個々の転位に関してもオリーブ ワイヤーを挿入して整復した。
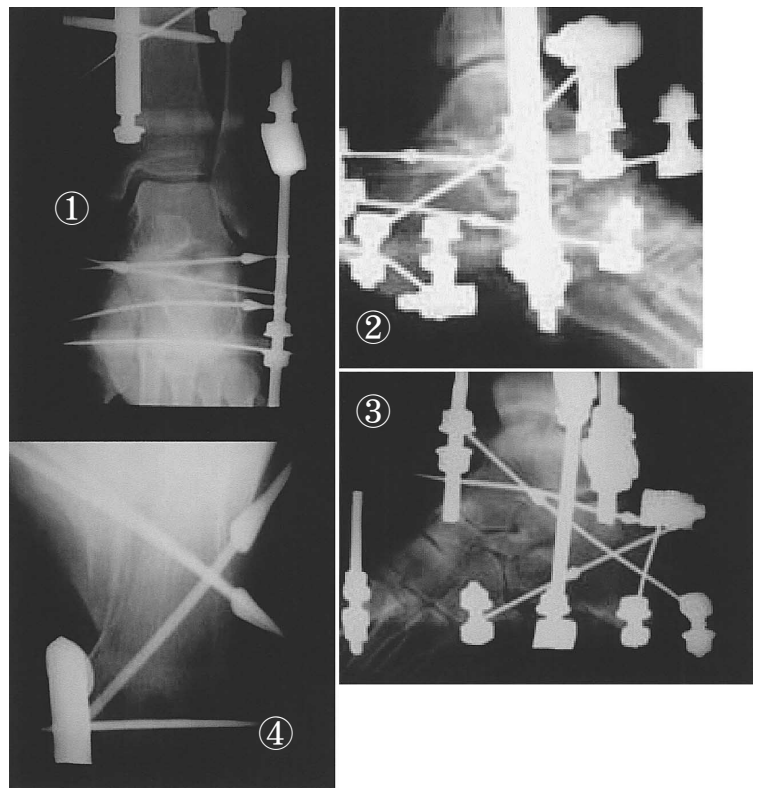

図 $4:$ 術後 X 線

(1)正面像 (2)測面像

(3)軸斜像 (4)Anthonsen 内斜位像

で逸脱していた（図 2)。血糖コントロールのため 2 週間の待機期間を要したが，受傷前から存在していた 両下腿の浮腫と受傷後出現した足部の腫脹は残存して いた。

手術方法：はじめに脛骨と踵骨にリングを装着し，垂 直方向に毫引をかけ，骨片間の陥入を可及的に取り除 き,オリーブワイヤーでの整復操作を追加した．距踵
関節面の高さがあっていることを確認した上で，内外 側よりオリーブワイヤーを用いて圧迫を加え，側方転 位の整復を行った。 また，個々の転位に関してもオリー ブワイヤーを挿入して整復した，更に，整復位を保持 するためワイヤーを数本追加挿入した（図 3 ). 術後 の単純 X 線（図 4) と実際の写真である。この手術 に際しては, 皮切は加えずに整復固定が可能であった 

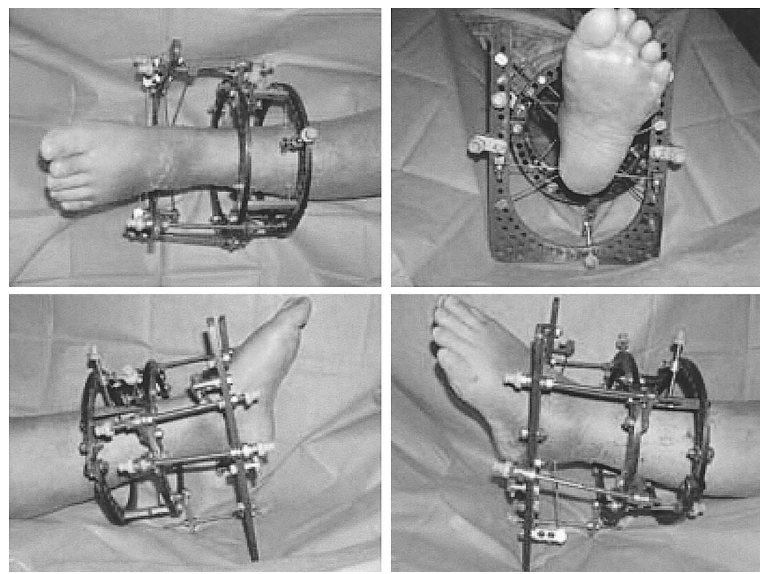

図 5 ：イリザロフ創外固定器装着時

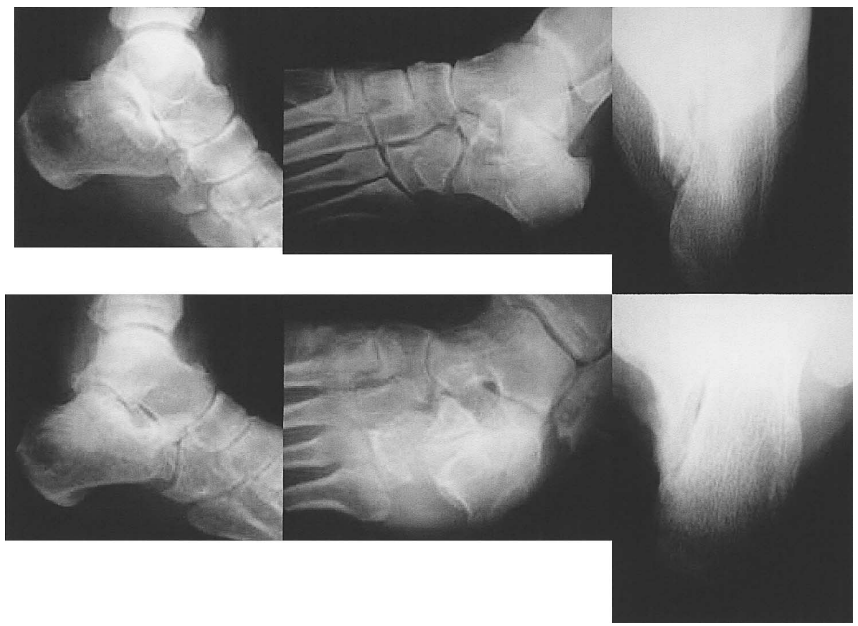

図 6：術前と術後 32 週の単純 X 線を比較したものである. 骨癒合は良好であった。

(上段：術前 下段：術後 32 週)

(図 5 ).

治療経過：術後 4 週で荷重を開始し，6 週で一本杖歩 行とした. 8 週で創外固定器を抜去し, 足関節の可動 域訓練を開始した。10 週で退院となり，外来でリ八 ビリを継続した。図 6 は術前之術後 32 週の単純 X 線 を比較したものである。骨癒合は良好であった（図 6 ). 図 7 は術前之術後 32 週の単純 CT を比較したもので ある，後距踵関節の脱其骨折は整復され，骨癒合して
いる (図 7 ). 図 8 の样に術後 32 週現在，歩行時痛や $\mathrm{ROM}$ の左右差はなく，経過良好であった（図 8 ）.

考察

踵骨骨折に対する治療法は観血的治療の選択を主張 する報告があり ${ }^{1)}$ ，また，観血的治療法の中でむ Westhues 法を用いた整復法の有用性は，以前より認 められている2).これまで当科でも施行してきたが， 


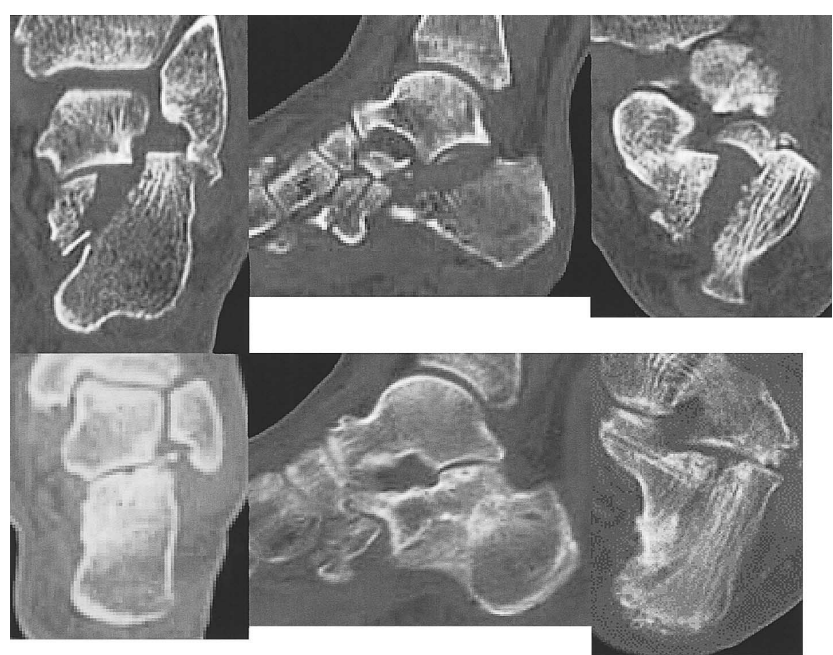

図 7 : 術前と術後 32 週の単純 CT を比較したものである. 後距踵関節の脱臼骨折は整復され, 骨癒合している. (上段：術前 下段：術後 32 週)
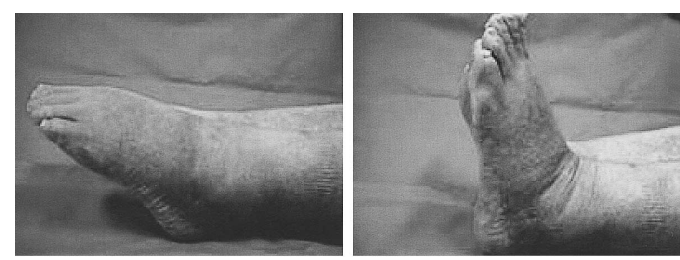

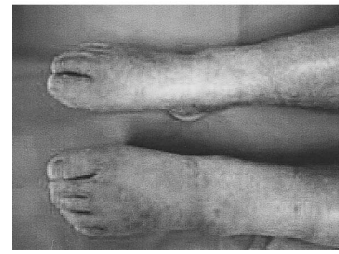

（底屈）

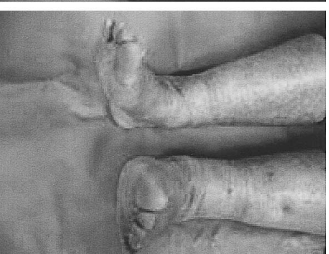

(背屈)
図 8 : 術後 32 週現在, 歩行時痛や $\mathrm{ROM}$ の 左右差はなく, 経過良好であった。

症例によっては balooning の整復が困難なものもあ る ${ }^{3)}$. Ilizarov 創外固定器は遠位主骨片に牽引を掛け ることで，かみこんだ骨片間の over lap を取り除き, その状態の保持を器械自体がしてくれるため, 関節面 や骨片間の整復が容易となる。更に，オリーブワイヤー を使用することで, 個々の離れた骨片の整復や, balooning の改善が可能である ${ }^{3,4}$. また, 踵骨プレー
トによる治療法の有用性屯認められているが ${ }^{5,6)}$ ，今 回のような高度な転位を伴う骨折の場合，皮切を加え なければ関節面の整復は困難であったと考えられる。 しかし，踵骨プレート等による固定は皮切が比較的大 きいため, 腫脹や浮腫が存在する症例には選択しづら く，長い待機期間を要することもある． Ilizarov 創外 固定器は皮切が不要なため, 腫脹や浮腫が存在する症 例でも縫合不全や皮膚壊死の危険性が少ない点も有用 である。しかし，機械操作がやや煩雑であり，ある程 度の熟練を要すること，術中，ピン操作時の神経・血 管損傷や術後のピントラクト感染の危険性があること. 装着後, 器械自体がかさばり, 患者がストレスを感じ る場合があることなどを問題点として留意する必要が あるだろう。踵骨骨折に対しての Ilizarov 創外固定 器の使用経験は, 当科であ少ないが, 今回のように良 好な結果を得られたことで，今後も症例を増やしてい こうと考えている。

\section{ま と め}

著明な転位を来たし，踵骨の粉砕を伴った距踵関節 脱臼骨折に対して Ilizarov 創外固定器を使用した。 術後 32 週現在, 歩行時痛や $\mathrm{ROM}$ の左右差はなく, 経過良好であった。 


\section{参 考 文 献}

1) Essex-Lopresti, P. : The mechanism, reduction technique and result in fractures of the os calcis. Br. J. Surg., 39 : 395-419, 1952.

2）三村 寛：踵骨骨折に対するプレートによる治療法. 手術, 45：1123-1127， 1991.

3）三村 寛，弓削大四郎：踵骨関節内骨折に対する Lanzetta 踵骨プレートの治療成績. MB Orthop., 8(2)：
73-81, 1995.

4）永田義紀：踵骨骨折に対するWesthues 法と観血的整 復法. MB Orthop., 8(2)：65-72, 1995.

5) 大関 覚：腫骨骨折に対する観血的治療法. MB Orthop., 8(2): 83-94, 1995.

6) Paley, D., et al. : Open reduction and circular external fixation of intraaticular calcaneal fractures. Clin. Orthop., 290 : 125-131, 1993. 